\title{
A NEW APPROACH TO THE ASSESSMENT OF EFFECTIVE MANAGEMENT OF GAS SUPPLY DIVERSIFICATION
}

\author{
Oleh DZOBA', Liliya MARYNCHAK², Oleksandra ROMASHKO \\ Ivano-Frankivsk National Technical University of Oil and Gas, Ukraine
}

\begin{abstract}
The purpose of the paper is to study the current state and trends in the development of the basic indicators of the EU gas sector, to generalize the theoretical and methodological approaches to calculating the gas diversification factor, assess and analyze its level in the EU countries in 2001-2015, and study the experience of European countries in addressing the diversification problems. Methodology. The methodological basis of the study was the works of domestic and foreign scientists devoted to the issues of gas supply diversification. The study is based on the analysis of the gas sector indicators and used analysis, synthesis, combination grouping and statistical-economic methods. Results of the of the study showed that in the EU countries in recent years there has been a noticeable tendency to reduce natural gas reserves, reduce the level of its production and increase consumption, which leads to an increase in import dependence. The largest consumers of natural gas in the EU are the United Kingdom, Germany, Italy, the Netherlands and France. The main external importers of pipeline gas to the EU countries are the Russian Federation, Algeria and Norway, and liquefied gas - Qatar, Algeria and Nigeria. It is established that at the end of 2015, the most diversified gas supply is to countries such as France, Belgium and Italy; a low level of gas supply diversification is observed in Hungary, Poland and Greece. Practical implications. The analysis of basic indicators which characterize the state and development of trends of the European gas market in 2000-2015 is carried out. The assessment and analysis of the level of diversification of natural gas supplies in the EU countries in 2001-2015 have been analyzed. Value/originality. It was proposed an original approach to calculate the gas diversification factor, which takes into account both the number of sources and the structure of the volumes of supplies from different sources.
\end{abstract}

Key words: natural gas, proved reserves, extraction, consumption, gas supply, diversification, index of diversification.

JEL Classification: L71, L95, O13, L11, F50

\section{Introduction}

One of the main conditions for the state economical securityis an effective energypolicyon sustainable energy supplies. Currently, global energy sector is characterized by limitations and exhaustion of hydrocarbon reserves, an imbalance between the availability of domestic energy resources and their demand, an increasing demand for energy, fluctuations in energy prices and increasing environmental requirements for their use.

\section{Trends of EU gas market}

The current state of the EU gas market is characterized by the following trends:

- reduction of proved reserves;

- decline in natural gas production;

- the increasing demand for natural gas;
- rising import dependence;

- the attempts of some EU countries to diversify domestic gas market through alternative sources and routes of gas supply.

Proved reserves of the European Union according to the British company British Petroleum at the end of 2000 were estimated at 3.82 trillion $\mathrm{m} 3$ (2.5\% of world reserves), and at the end of 2010 they decreased to 2.44 trillion $\mathrm{m} 3$ which is only $1.3 \%$ of world reserves and is the lowest among all regions. It should be noted that gas is extracted by only 7 countries out of the 27 countries of EU (Table 1 ).

As shown in Table 1, the most significant natural gas reserves, the value of which at the end of the analyzed period amounted to 0.7 trillion $\mathrm{m} 3(63.6 \%)$ can be found in the Netherlands. We should note the annual negative trend towards reducing the resource base by

\footnotetext{
Corresponding author:

${ }^{1}$ Department of Theory of Economics and Management, Ivano-Frankivsk National Technical University of Oil and Gas.

E-mail: dzoba1960@gmail.com

${ }^{2}$ Department of Finance, Ivano-Frankivsk National Technical University of Oil and Gas.

E-mail:1marynchak@yahoo.com

${ }^{3}$ Department of Finance, Ivano-Frankivsk National Technical University of Oil and Gas.

E-mail: romashka-ua@mail.ru
} 
increasing production of hydrocarbons and reducing the proportion of the finding of large fields.

At the end of 2000 the United Kingdom had a significant share of natural gas reserves -1.2 trillion $\mathrm{m}^{3}$ (31.4\%), but due to the exhaustion of gas fields during 15 years, the resource base has decreased by 6 times (to the level of 0.2 trillion).

Romania is the only EU country which during the reviewed period was characterized by the growth of the resource base. Proved natural gas reserves of the country in 2005 due to the detection of hydrocarbons in the area of Snake Island have doubled in comparing with the previous analyzed period and came up to 0.63 trillion $\mathrm{m}^{3}$. In 2005 a foreign investor, the Austrian oil company OMV, came to Romania, which had bought $35 \%$ of shares of Parent Petroleum Romanian company Petrom, and signed an agreement on developing the shelf. Thus, Romania at the end of 2010 took a second place (24.5\%) among the EU countries on proved reserves.

During the analyzed period Poland had proved reserves of gas in 0,1-0,12 trln. $\mathrm{m}^{3}$. Poland is the only EU country which for the past 15 years was characterized by stabilization of the resource base. One of the largest gas fields in the EU - Przemysl-Yaksmanitse lies in this country.

Most European countries don't have their own natural gas deposits due to the unbalanced distribution of natural gas resources. The general trend during analyzed period is stabilization of proved natural gas reserves in Poland and the decline in proved reserves in other EU countries. According to British Petroleum, the deposits of natural gas in the EU under the existing extraction volume and unchanged stocks would last only for 11 years (comparing the production volumes and proved reserves of natural gas according to the data of 2015). Thus, the limited internal resource base is typical for this region.

The major trends in the volume of extraction depend not only on natural gas reserves, but on the volume of exploration, development of new deposits and implementation of new technologies. Indicators of natural gas in the EU are shown in Table 2.

The data in Table 2 show a slight decline of extraction in 2000-2004 and increase of reduction of gas production in the coming years. In 2015, the annual natural gas extraction in Europe decreased to 120.1 billion $\mathrm{m}^{3}$, representing $3.4 \%$ of world production. This trend is due to the exhaustion of gas fields, complication of terms of gas production, reduction in exploration work and proved reserves.

The largest share of gas extraction during 2000-2008 was from the UK, but in 2000 the country produced 108.4 billion $\mathrm{m}^{3}$ ( $46.7 \%$ of total EU production), whereas in 2015 only 39.7 billion $\mathrm{m}^{3}$ ( $33 \%$ of total production), which is almost three times less. This

Table 1

Proved reserves of natural gas in the EU, trillion $\mathbf{m}^{3}$

\begin{tabular}{|c|c|c|c|c|c|c|c|c|c|}
\hline \multirow{2}{*}{ Country } & \multicolumn{9}{|c|}{ Period } \\
\hline & 2000 & 2002 & 2004 & 2006 & 2008 & 2010 & 2012 & 2014 & 2015 \\
\hline Netherlands & 1,50 & 1,43 & 1,33 & 1,22 & 1,14 & 1,17 & 0,8 & 0,7 & 0,7 \\
\hline Great Britain & 1,20 & 1,00 & 0,83 & 0,41 & 0,29 & 0,26 & 0,2 & 0,2 & 0,2 \\
\hline Romania & 0,34 & 0,31 & 0,30 & 0,63 & 0,62 & 0,60 & 0,1 & 0,1 & 0,1 \\
\hline Germany & 0,22 & 0,19 & 0,16 & 0,13 & 0,10 & 0,07 & 0,1 & $<0,05$ & $<0,05$ \\
\hline Italy & 0,18 & 0,16 & 0,11 & 0,09 & 0,06 & 0,08 & 0,1 & $<0,05$ & $<0,05$ \\
\hline Denmark & 0,14 & 0,13 & 0,12 & 0,12 & 0,06 & 0,05 & $<0,05$ & $<0,05$ & $<0,05$ \\
\hline Poland & 0,12 & 0,12 & 0,11 & 0,11 & 0,11 & 0,12 & 0,1 & 0,1 & 0,1 \\
\hline
\end{tabular}

(BP Statistical Review of World Energy, June 2011 - June 2016)

Table 2

The volume of the natural gas extraction in the EU, billion $\mathbf{m}^{3}$

\begin{tabular}{|c|c|c|c|c|c|c|c|c|c|}
\hline \multirow{2}{*}{ Country } & \multicolumn{9}{|c|}{ Period } \\
\hline & 2000 & 2002 & 2004 & 2006 & 2008 & 2010 & 2012 & 2014 & 2015 \\
\hline Netherlands & 58,1 & 60,3 & 68,5 & 61,6 & 66,6 & 70,5 & 63,8 & 55,7 & 43,0 \\
\hline Great Britain & 108,4 & 103,6 & 96,4 & 80,0 & 69,6 & 57,1 & 38,9 & 36,8 & 39,7 \\
\hline Romania & 13,8 & 13,2 & 12,8 & 11,9 & 11,4 & 10,9 & 10,0 & 9,7 & 10,3 \\
\hline Germany & 16,9 & 17,0 & 16,4 & 15,6 & 13,0 & 10,6 & 9,0 & 7,7 & 7,2 \\
\hline Italy & 15,2 & 13,4 & 11,9 & 10,1 & 8,5 & 7,6 & 7,8 & 6,5 & 6,2 \\
\hline Denmark & 8,2 & 8,4 & 9,4 & 10,4 & 10,1 & 8,2 & 5,8 & 4,6 & 4,6 \\
\hline Poland & 3,7 & 4,0 & 4,4 & 4,3 & 4,1 & 4,1 & 4,3 & 4,1 & 4,1 \\
\hline $\begin{array}{l}\text { Other UE } \\
\text { countries }\end{array}$ & 7,6 & 7,7 & 7,5 & 7,4 & 6,1 & 5,9 & 7,1 & 5,4 & 5 \\
\hline EU & 231,9 & 227,6 & 227,3 & 201,3 & 189,4 & 174,9 & 146,7 & 130,5 & 120,1 \\
\hline
\end{tabular}

(BP Statistical Review of World Energy, June 2011 - June 2016) 
negative trend is due to the exhaustion of most fields. Due to the sufficient volume of proven reserves and commissioning of new gas fields on the North Sea offshore, Netherlands managed to increase production during the years $2000-2010$ by 12.4 billion $\mathrm{m}^{3}$, which brought this country to the position of the largest distributors of gas in the EU.

As shown in Table 2, the Netherlands $(35.8 \%$ of production in 2015) and the UK (33\%) were the largest producers of gas among European countries. These two countries account for almost $70 \%$ of the extracted natural gas in the EU. The smallest volume of natural gas is produced in Poland.

Overall in 2000-2015 gas production in the EU decreased. The largest reduction in gas production was noted in the UK. The EU is the only region in the world where over the last 15 years the extraction volume of gas has decreased.

Consumption of natural gas in the country depends on economic growth, industrialization, industrial policy and the development of other energy resources, table 3.

As shown in Table 3, overall gas demand in the EU increased by 2010 and reached the maximum level of consumption during the analyzed decade 492.5 billion $\mathrm{m}^{3}$. During the following years there was a $22 \%$ reduction in demand. According to the results of 2015 , the volume of natural gas increased by $4.5 \%$ compared to the previous period. Overall consumption in the European Union over the last fifteen years decreased by $8.7 \%$.

The structure of natural gas consumption in some countries remained virtually unchanged throughout the period under review, which indicates the inertia of energy sectors of these countries and dependence of national economies on the appropriate resources. Geography of gas consumption is characterized as follows: $70 \%$ gas (based on 2015) accounted for 5 European countries (UK, Germany, Italy, the Netherlands and France). At the same time, the share of gas consumption in Bulgaria, Denmark, Greece, Finland, Lithuania and Sweden is less than $1 \%$ of total EU volume.

During the period under review in the EU there was a growing imbalance between the volume of consumption and production of natural gas. Dynamics of natural gas deficit is negative, because it has a clear upward trend. Thus, if the European Union in 2000 met the demand of gas production at $52.66 \%$, in 2010 - only at $29.87 \%$. Therefore, a feature of the European gas market is characterized as high level of import dependence .

According to the forecasts of a British company "British Petroleum" in the long run out of the extractive energy resources there will be an increasing demand for natural gas due to its more favorable environmental characteristics (BP world development forecast: Forecast of World Energy Development 2030).

The increase in gas demand in the EU is predetermined by (Saprykin V., 2004):

- The prospect of the nuclear power plants shutdown in some EU countries (Germany, Switzerland, Belgium). May 30, 2011 the German government announced its decision to close by 2022 all 17 nuclear reactors, which today produce about $23 \%$ of electricity. Switzerland by 2034 plans to close all five nuclear power plants, which account for about $40 \%$ of energy in the country. The gradual closure of the Belgian nuclear power plants to be completed by 2025;

- The need to supply natural gas to certain regions of the $\mathrm{EU}$, which still do not receive it due to the construction of new gas pipelines;

- Increasing number of the EU member states (Croatia became the 28th member of the EU July 1, 2013, candidates for the EU membership are Albania, Iceland, Macedonia, Serbia, Turkey and Montenegro, possible candidate are Bosnia and Herzegovina, Kosovo).

Due to the absence of its own resource base, European countries have to import natural gas, Table 4.

A characteristic feature of the European gas market during the years of 2009-2015 was stable level of import dependance (except 2014), since the volume of imported natural gas was almost at the same level, although since 2011 there was a downward trend in import.

Partially deficit of natural gas is covered by domestic import - from Denmark and the Netherlands. The major foreign importers of pipeline gas to the EU are the Russian Federation, Algeria and Norway. Certain amounts of gas to European countries are transmitted from Libya. It should be noted that big share of imported

Table 3

EU gas balance

\begin{tabular}{|c|c|c|c|c|c|c|c|c|c|}
\hline \multirow{2}{*}{ Indicators } & \multicolumn{9}{|c|}{ Period } \\
\hline & 2000 & 2002 & 2004 & 2006 & 2008 & 2010 & 2012 & 2014 & 2015 \\
\hline $\begin{array}{l}\text { Consumption } \\
\text { volume, billion. } \mathrm{m}^{3}\end{array}$ & 440,4 & 451,2 & 486,0 & 486,9 & 489,7 & 492,5 & 439,8 & 384,5 & 402,1 \\
\hline $\begin{array}{l}\text { Extraction volume, } \\
\text { billion } \mathrm{m}^{3}\end{array}$ & 231,9 & 227,6 & 227,3 & 201,3 & 189,4 & 174,9 & 146,7 & 130,5 & 120,1 \\
\hline Deficit,, billion $\mathrm{m}^{3}$ & 208,5 & 223,6 & 258,7 & 285,6 & 300,3 & 317,6 & 293,1 & 254 & 282 \\
\hline $\begin{array}{l}\text { Ratio of energy } \\
\text { dependence, \% }\end{array}$ & 47,34 & 49,56 & 53,23 & 58,66 & 61,32 & 64,49 & 66,64 & 66,06 & 70,13 \\
\hline
\end{tabular}

(BP Statistical Review of World Energy, June 2011 - June 2016) 
Table 4

Assessment of the indicators of natural gas import to the EU

\begin{tabular}{|c|c|c|c|c|c|c|c|}
\hline \multirow{2}{*}{ Indicator } & \multicolumn{7}{|c|}{ Period } \\
\hline & 2009 & 2010 & 2011 & 2012 & 2013 & 2014 & 2015 \\
\hline $\begin{array}{l}\text { Gas imports to the EU, billion } \mathrm{m}^{3} \\
\text { including }\end{array}$ & 411,6 & 418,9 & 405,5 & 404,3 & 396,9 & 362,2 & 409,2 \\
\hline - via pipelines & 331,7 & 334,1 & 345 & 358,9 & 355,2 & 320,8 & 361,7 \\
\hline - LNG & 79,8 & 84,9 & 60,5 & 45,4 & 41,7 & 41,4 & 47,5 \\
\hline including imports of Russian gas & 110,4 & 117,1 & 105,5 & 136,2 & 136,2 & 120,8 & 133,2 \\
\hline $\begin{array}{l}\text { The volume of gas transit through } \\
\text { Ukraine to the EU, billion } \mathrm{m}^{3}\end{array}$ & 92,8 & 95,4 & 101,1 & 81,2 & 83,7 & 59,4 & 64,2 \\
\hline The share of imported Russian gas, $\%$ & 26,82 & 27,95 & 26,02 & 33,69 & 34,32 & 33,35 & 32,55 \\
\hline $\begin{array}{l}\text { The share of Ukraine's GTS transit in } \\
\text { import, \% }\end{array}$ & 22,55 & 22,77 & 24,93 & 20,08 & 21,09 & 16,40 & 15,69 \\
\hline $\begin{array}{l}\text { The share of Ukraine's GTS transit in } \\
\text { Russian gas, \% }\end{array}$ & 84,06 & 81,47 & 95,83 & 59,62 & 61,45 & 49,17 & 48,20 \\
\hline
\end{tabular}

(BP Statistical Review of World Energy, June 2011 - June 2016)

gas during 2009-2011 came from Russia (26-28\%), and in 2012 - up to $34 \%$, therefore European countries have become more dependent on Russian gas. Thus, one third of the analyzed energy resources to EU countries comes from Russia, but due to the international standards of security energy supplies from other sources should not exceed 25\% (Volovich A.).

Diversification of natural gas supply to the European Union is provided by LNG technology, which is natural gas transportation in liquefied state using special gas carriers.

Belgium, France, Greece, Italy, Spain, Portugal and the United Kingdom are the LNG consumers among the Europien countries. The main importers are Qatar, Algeria and Nigeria. Certain amounts of liquefied natural gas European countries get from Norway, Peru, Trinidad and Tobago, Egypt, Emena, Oman, Equatorial Guinea and Libya.

It should be noted that during the analyzed period the ratio between the volume of natural gas transportation by pipelines and by LNG technology has changed towards increasing the main pipeline transportation.

A significant deficit of energy in the EU causes the urgency of solving the problem of diversification of sources and routes of supply to domestic national markets.

\section{Indicators of diversification of gas supply}

The analysis of publications shows the lack of scientifically proved methodical approaches to evaluation of the diversification of certain types of energy resources to the national markets. Natural gas is no exception.

Considering the problem of diversification of gas supply for certain national markets, the share of the natural gas in the energy balance of the country should be taken into consideration, as well as the the number of external sources of gas supply, diversification of the transport infrastructure for gas to supply, and the share of gas coming from different sources.

To assess the impact of the diversification of gas supply we should reasonably measure its level using quantitative and qualitative indicators. To assess the level of diversification we suggest the following indicators (Dzoba O., 2012):

The absolute level of diversification. It is determined by the total number of independent gas suppliers. For more complete idea about the nature of diversification it would be desirable to allocate the number of suppliers by gas pipelines and LNG. In accordance with international standards, energy imports is considered reliable if the supply is carried out of at least three sources (Volovich A.), thus compliance with these conditions means that gas supply is diversified.

The maximum volume of supply from one source. According to the international criteria of energy security, energy supply from one source should not exceed $25 \%$ (Volovich A.), therefore the limiting volume of supply will be:

$$
Q m=0,25 * Q t \text {, }
$$

where $Q t$ - the total import volume of natural gas, $\mathrm{m} 3$.

The relative diversification coefficient, which takes into account the number of suppliers and their supply volumes.

$$
C_{d}=\frac{\sum_{i=1}^{n} Q i}{Q_{t}} * 100 \% \text {, }
$$

where $Q i$ - the amount of gas supplied by individual producer (from one source):

$$
Q_{i}=\left\{\begin{array}{lll}
Q_{i} & \text { if } & Q_{i} \leq Q_{m} \\
Q_{m} & \text { if } & Q_{i}>Q_{m}
\end{array}\right.
$$

$n$ - the number of sources of gas supply.

We propose the following grading diversification, which covers four main areas (table 5). 
Table 5

Gradation of the diversification level of gas supply

\begin{tabular}{|c|l|}
\hline The diversification Coefficient & \multicolumn{1}{|c|}{ Diversification Zone } \\
\hline $\mathrm{Cd}<50 \%$ & Critical diversification level \\
\hline $50 \% \leq \mathrm{Cd}<75 \%$ & Low diversification level \\
\hline $75 \% \leq \mathrm{Cd}<90 \%$ & Medium diversification level \\
\hline $\mathrm{Cd} \geq 90 \%$ & High diversification level \\
\hline
\end{tabular}

(Developed by the author)

It should be noted that this factor can be considered if the minimum condition of diversification is met, namely the energy supply is carried out of at least three sources.

\section{Evaluation of the diversication of gas supplies in the EU}

Using these indicators, we will analyze the principle of diversification of the EU countries, including the UK (table 6). The coefficients of diversification of gas supplies in Europe in the years 2001-2015 were summarized in table 7 .

The analysis showed that a high diversification level is typical for France and Spain, but during the last 2-3 years the diversification of gas supply has deteriorated. Belgium has achieved a high level during 2009-2011, and Italy - in 2010-2012.
For Germany diversification coefficient by 2012 was in medium rate, and over the next two years dropped to $73 \%$. Until 2005 the diversification rate in the UK was low, and the next four years were characterized by critical diversification, in 2010 the index moved to the average rate, but at the end of the reviewed period it was characterized by weak diversification again. For the Netherlands it was also characterized by variable diversification zones: low (2001-2002), medium (2003-2007), high (2008), medium (2009-2010) and low (2011-2014).

Critical diversification of sources and ways of natural gas supply is characteristic of Slovenia. Austria has optimized the partial gas supply since 2007 to reach a low level of diversification. In 2008 Greece also moved into this zone.

The critical diversification level of natural gas supply is observed in post-Soviet countries such as Hungary, Poland and Romania.

As for the otherEU countries, the partial diversification of gas supply is typical for the Czech Republic (imports gas from Norway and Russia), Luxembourg (during 2001-2002 carried supplies from Germany and the Netherlands, and since 2003 gas was imported from Belgium instead of Netherlands) and Sweden (since 2003 - two sources of natural gas supply).

Table 6

The volume of gas supply to the UK in 2001-2015, billion $\mathrm{m}^{3}$

\begin{tabular}{|c|c|c|c|c|c|c|c|c|c|c|c|c|c|c|c|}
\hline \multirow[t]{2}{*}{ Country } & \multicolumn{15}{|c|}{ Period } \\
\hline & 2001 & 2002 & 2003 & 2004 & 2005 & 2006 & 2007 & 2008 & 2009 & 2010 & 2011 & 2012 & 2013 & 2014 & 2015 \\
\hline Belgium & & & & 1,2 & 1,8 & 1,8 & 1,8 & 1,12 & 0,74 & 1,26 & & & & & \\
\hline Germany & & & 0,4 & 0,6 & 1,0 & 1,0 & 1,6 & & & & & & & & \\
\hline Netherlands & 0,5 & 1,1 & 0,5 & 0,5 & 0,3 & 0,6 & 8,2 & 9 & 6,44 & 8,07 & 6,4 & 7,3 & 9,5 & 6,6 & 3,1 \\
\hline Norway & 2,2 & 3,6 & 6,61 & 9,1 & 11,55 & 14,1 & 16,4 & 25,3 & 23,7 & 25,63 & 21,7 & 26,8 & 29,1 & 25,9 & 25,7 \\
\hline Other countries of EU & & & & & & & & & & & & 1,3 & 3,3 & 0,4 & 0,2 \\
\hline USA (LNG) & & & & & & & & & & 0,18 & & & & & \\
\hline $\begin{array}{l}\text { Trinidad and Tobago } \\
\text { (LNG) }\end{array}$ & & & & & 0,07 & 0,6 & 0,39 & 0,47 & 1,97 & 1,63 & 0,6 & & 0,1 & 0,4 & 0,4 \\
\hline Qatar (LNG) & & & & & & & 0,27 & 0,12 & 5,75 & 13,89 & 21,9 & 13,3 & 8,6 & 10,4 & 11,9 \\
\hline Yemen (LNG) & & & & & & & & & & 0,26 & 0,7 & & & & \\
\hline Norway (LNG) & & & & & & & & & 0,26 & 0,94 & 0,4 & 0,2 & 0,1 & & 0,1 \\
\hline Egypt (LNG) & & & & & & 0,96 & 0,16 & 0,08 & 0,51 & 0,12 & 0,1 & 0,1 & 0,1 & & \\
\hline Algeria (LNG) & & & & & 0,45 & 2,0 & 0,64 & 0,37 & 1,68 & 1,25 & 0,2 & 0,1 & 0,4 & 0,5 & 0,4 \\
\hline Australia (LNG) & & & & & & & & & 0,08 & & & & & & \\
\hline Nigeria (LNG) & & & & & & & & & & 0,4 & 1,3 & 0,1 & & & 0,1 \\
\hline $\begin{array}{l}\text { The total amount } \\
\text { bln.m }{ }^{3}\end{array}$ & 2,7 & 4,7 & 7,51 & 11,4 & 15,17 & 21,06 & 29,46 & 36,46 & 41,12 & 53,63 & 53,4 & 49,2 & 51,2 & 44,2 & 41,9 \\
\hline $\begin{array}{l}\text { The absolute level of } \\
\text { diversification of gas } \\
\text { supply (the number } \\
\text { of independent gas } \\
\text { suppliers) }\end{array}$ & 2 & 2 & 3 & 4 & 6 & 7 & 8 & 7 & 9 & 11 & 9 & 8 & 8 & 6 & 8 \\
\hline $\begin{array}{l}\text { The limited vo-lume of } \\
\text { supply, billion } \mathrm{m}^{3}\end{array}$ & 0,68 & 1,18 & 1,88 & 2,85 & 3,79 & 5,27 & 7,37 & 9,12 & 10,28 & 13,41 & 13,33 & 12,30 & 12,80 & 11,05 & 10,48 \\
\hline $\begin{array}{l}\text { The Coefficient of } \\
\text { diversifica-tion, \% }\end{array}$ & 43,52 & 48,40 & 36,98 & 45,18 & 48,86 & 58,05 & 66,50 & 55,61 & 67,38 & 77,21 & 84,29 & 68,50 & 68,16 & 66,40 & 60,26 \\
\hline
\end{tabular}

(BP Statistical Review of World Energy, June 2011 - June 2016) 
Vol. 3, No. 1, 2017

Baltic Journal of Economic Studies

Table 7

Diversification ratios of gas supply of the EU countries in 2001-2015, \%

\begin{tabular}{|c|c|c|c|c|c|c|c|c|c|c|c|c|c|c|c|}
\hline \multirow{2}{*}{ Country } & \multicolumn{15}{|c|}{ Period } \\
\hline & 2001 & 2002 & 2003 & 2004 & 2005 & 2006 & 2007 & 2008 & 2009 & 2010 & 2011 & 2012 & 2013 & 2014 & 2015 \\
\hline Germany & 81,93 & 82,87 & 81,28 & 80,10 & 79,39 & 78,95 & 79,18 & 78,13 & 80,45 & 79,30 & 76,37 & 75,92 & 73,41 & 72,12 & 72,98 \\
\hline Italy & 74,54 & 81,49 & 82,98 & 83,73 & 83,92 & 88,76 & 88,70 & 86,33 & 89,16 & 90,56 & 94,40 & 94,16 & 81,32 & 83,64 & 82,37 \\
\hline France & 92,17 & 92,61 & 93,08 & 91,47 & 96,04 & 95,75 & 92,67 & 92,72 & 92,49 & 97,10 & 93,66 & 85,57 & 85,56 & 80,20 & 84,53 \\
\hline Spain & 83,30 & 91,29 & 91,51 & 97,37 & 96,62 & 100,00 & 99,95 & 100,00 & 100,00 & 100,00 & 99,39 & 95,61 & 87,38 & 88,84 & 74,82 \\
\hline Austria & 38,58 & 46,80 & 49,32 & 48,08 & 46,66 & 46,53 & 50,13 & 53,40 & 56,83 & 47,45 & 72,92 & 71,05 & 50,00 & 50,00 & 50,0 \\
\hline Belgium & 68,57 & 74,62 & 83,99 & 73,12 & 74,89 & 78,92 & 76,25 & 75,02 & 91,69 & 97,23 & 100,00 & 95,36 & 83,84 & 91,67 & 84,06 \\
\hline Great Britain & 43,52 & 48,40 & 36,98 & 45,18 & 48,86 & 58,05 & 66,50 & 55,61 & 67,38 & 77,21 & 84,29 & 68,50 & 68,16 & 66,40 & 60,26 \\
\hline Hungary & 45,26 & 37,80 & 39,47 & 39,89 & 48,11 & 49,02 & 50,10 & 47,61 & 36,11 & 38,39 & 39,93 & 43,63 & 25,0 & 25,0 & 25,0 \\
\hline Poland & 35,71 & 32,79 & 35,57 & 38,19 & 62,32 & 58,77 & 58,33 & 51,53 & 46,86 & 35,54 & 39,68 & 43,18 & 40,79 & 41,04 & 45,72 \\
\hline Nether-lands & 50,99 & 65,33 & 83,26 & 85,03 & 89,36 & 87,22 & 83,72 & 90,39 & 80,84 & 77,21 & 66,79 & 69,83 & 64,53 & 72,41 & 63,62 \\
\hline Greece & 50,00 & 48,92 & 50,00 & 45,00 & 41,08 & 41,96 & 46,89 & 57,37 & 62,69 & 71,91 & 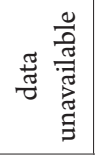 & 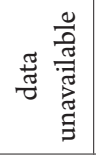 & 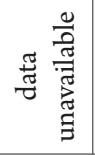 & 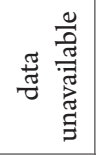 & 49,0 \\
\hline Slovenia & 50,00 & 50,00 & 50,00 & 59,09 & 59,09 & 59,09 & 59,09 & 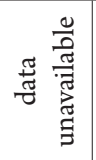 & 50,00 & 50,00 & 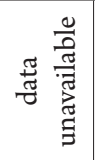 & 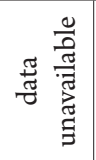 & 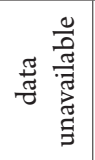 & 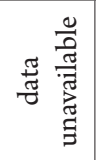 & 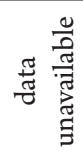 \\
\hline Portugal & 35,57 & 41,35 & 50,00 & 50,00 & 50,00 & 50,00 & 50,00 & 51,10 & 71,32 & 66,73 & 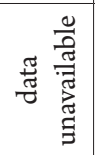 & 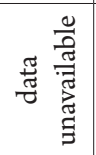 & 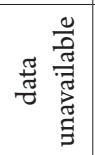 & 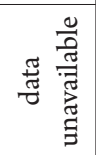 & 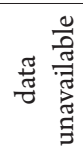 \\
\hline Romania & 31,67 & 30,41 & 33,62 & 47,03 & 61,80 & 61,80 & 70,83 & 47,22 & 25,00 & 25,00 & 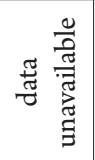 & 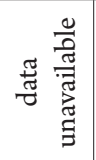 & 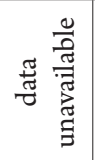 & 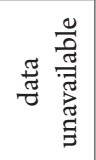 & 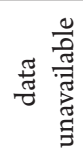 \\
\hline
\end{tabular}

(BP Statistical Review of World Energy, June 2011 - June 2016)

The other EU countries import the entire volume of natural gas from one supplier: Bulgaria, Finland, Lithuania, Latvia and Slovakia from Russia, and Ireland from Britain. These countries are in a position that is internationally called critical monopoly dependence, because they are $100 \%$ depended on one gas supplier.

To increase gas diversification in EU, countries should deepen cooperation with countries - suppliers and transit countries of energy resources, conduct a search for alternative exporting countries, develop diverse routes and introduce new technologies. In addition, countries when developing their own strategies of gas supply should not only consider the pros and cons of diversification, but the ratio of supply from different sources and the risk of abusing the energy security.

\section{Conclusions}

As a result of research the original approach to the evaluation of the diversification level of gas supply to individual national markets was offered, which takes into account the number of sources and the structure of supply from various sources, and the diversification level of natural gas supply to the EU countries was analyzed.

It was found that in EU countries in recent years there has been a noticeable tendency to depletion of natural gas reserves, reducing its production and growth of consumption, which leads to the increase of the import dependence. EU demand in natural gas by domestic production was met in 2015 only by $29.87 \%$.

The largest consumers of natural gas in the EU are the United Kingdom, Germany, Italy, the Netherlands and France. The major foreign importers of pipeline gas to the EU are the Russian Federation, Algeria and Norway, and LNG - Qatar, Algeria and Nigeria.

To reduce energy dependence, EU countries should diversify sources and routes of energy supply to ensure their own energy security. By the end of 2015 the most diversified gas supply countries were France, Belgium and Italy; the lowest level of diversification of gas supplies can be noted in Hungary, Poland and Greece. 


\section{References:}

BP Statistical Review of World Energy, June 2011 - June 2016 [Electronic resource]. - Access mode: http://www.bp.com.

BP: BP world development forecast: Forecast of World Energy Development 2030 [Electronic resource]. Retrieved from: http://www.bp.com/liveassets/bp_internet/russia/bp_russia_russian.

(2008). Diversification projects in Ukraine's energy sector: state, problems and ways of their realization // National Security and Defence - Ukrainian Centre for Economic and Political Studies named after Razumkov, № 6, p. 2-53. Dzoba, O. (2012). Evaluation of diversification of natural gas supply in the European - Scientific journal "Economic Journal - XXI", № 7-8, p. 37-40.

Saprykin, V. (2004). "Gas triangle" EU-Ukraine-Russia: unity and struggle of interests - Zerkalo Nedeli, №8 (332). Volovich, A. Diversification prospects of energy supply to Ukraine [Electronic resource]. - Retrieved from: http://www.niss.gov.ua/Monitor/mart2009/5.htm.

\section{Олег ДЗЁБА, Лилия МАРИНЧАК, Александра РОМАШКО \\ НОВЫЙ ПОДХОД К ОЦЕНКЕ ЭФФЕКТИВНОГО УПРАВЛЕНИЯ ДИВЕРСИФИКАЦИЕЙ ГАЗОСНАБЖЕНИЯ}

Аннотация. Целью статьи является исследование современного состояния и тенденций развития базовых показателей газового сектора ЕС, обоснование теоретико-методологических подходов к расчету коэффициента диверсификации газоснабжения, оценка и анализ его уровня в странах ЕС в 2001-2015 годах, изучение опыта европейских стран в решении проблем диверсификации. Методологической базой исследования стали труды отечественных и зарубежных ученых, посвященные вопросам диверсификации газоснабжения. Исследование основано на проведении анализа показателей газового сектора и основывается на методах анализа, синтеза, комбинационного группирования и статистическо-экономическом методе. Результаты исследования показали, что в странах Евросоюза в последние годы наблюдалась заметная тенденция к сокращению запасов природного газа, снижение уровня его добычи и рост объемов потребления, что приводит к росту импортозависимости. Крупнейшими потребителями природного газа в ЕС являются Великобритания, Германия, Италия, Нидерланды и Франция. Основными внешними импортерами трубопроводного газа в страны ЕС являются Российская Федерация, Алжир и Норвегия, а сжиженного газа - Катар, Алжир и Нигерия. Установлено, что на конец 2015 года самым диверсифицированным является газоснабжение таких стран, как Франция, Бельгия и Италия; низкий уровень диверсификации газоснабжения отмечается в Венгрии, Польше и Греции. Практическое значение. Проведен анализ базовых показателей, характеризующих состояние и тенденции развития европейского газового рынка за 20002015 годы. Осуществлены оценка и анализ уровня диверсификации поставок природного газа в странах ЕС в 2001-2015 годах. Значение/оригинальность. Предложен оригинальный подход к расчету коэффициента диверсификации газоснабжения, который учитывает как количество источников, так и структуру объемов поставок из разных источников. 